\title{
Foucault e Rancière: aprender e apreender-se no dissenso
}

\author{
Mariana Freitas Alvim' \\ https://orcid.org/0000-0002-0165-2962 \\ I - PUC-SP \\ São Paulo (SP). Brasil
}

MARQUES, A.C.S.; PRADO, M.A.M.

Diálogos e dissidências. Michel

Foucault e Jacques Rancière. Curitiba,

Appris, 2018, 186 p.

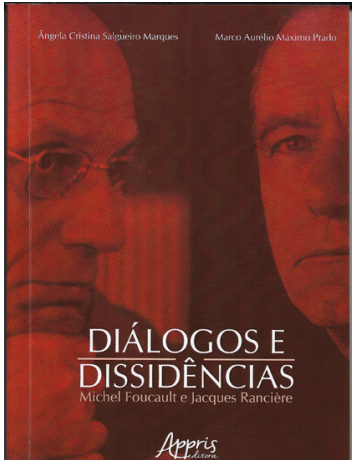

Resumo: No livro Diálogos e dissidências: M. Foucault e J. Rancière, os autores apresentam uma síntese das trajetórias teóricas e os principais conceitos destes pensadores, fundamentais na filosofia política contemporânea. São trabalhadas concordâncias e particularidades em suas obras, sobretudo no que diz respeito às possibilidades de emancipação dos indivíduos diante do poder.

Palavras-chave: filosofia moderna; filosofia política; Foucault; Rancière; subjetivação; poder.

Abstract: Foucault and Rancière: learning and apprehending in dissent - In the book Diálogos e Dissidências: M. Foucault and J. Rancière, the authors present a synthesis of the theoretical paths and main concepts of these thinkers, essential in contemporary political philosophy. Agreements and particularities in their work are detailed, especially with regard to the possibilities of emancipation of individuals in the face of power.

Keywords: modern philosophy; political philosophy; Foucault; Rancière; subjectivation; power.

Em tempos nos quais a ebulição política pronuncia-se e a pós-verdade desafia saberes cientificamente consolidados - questionando dos benefícios das vacinas à existência das mudanças climáticas -, é no mínimo enriquecedor voltar-se para dois dos principais pensadores da filosofia política contemporânea, que fizeram do conhecimento, do poder e da emancipação núcleos essenciais de suas obras. Michel Foucault e Jacques Rancière têm parte de seus pensamentos apresentados, em seus pontos de encontro e contrastes, 
no livro Diálogos e dissidências: M. Foucault e J. Rancière, de Ângela Cristina Salgueiro Marques e Marco Aurélio Máximo Prado (UFMG).

Como destaca no prefácio Jean-Luc Moriceau, professor no Institut Mines-Télécom (França), Foucault e Rancière unem-se na crítica à autoridade do saber, que se reflete no furto pelo mundo intelectual e acadêmico da fala do "povo" e, em alguns casos, na não apreensão do que dizem e sabem as massas. Em um dos vários trechos originais costurados com o texto de Marques e Prado no livro, lembrou Foucault em entrevista a Gilles Deleuze em 1972: "O que os intelectuais descobriram depois da recente arremetida é que as massas não necessitam deles para saber; elas sabem perfeitamente, claramente, muito melhor do que eles; e elas o dizem muitíssimo bem" (FOUCAULT, 2012, p. 29) apud MARQUES; PRADO; 2018, p. 29). Nos tempos atuais, isto pode ser mais do que enriquecedor, mas uma provocação sobre a colocação dos intelectuais nas disputas de saberes.

Qual é, assim, o papel do intelectual proposto por Foucault e Rancière? O primeiro dos quatro capítulos do livro expõe a proposição metodológica de Foucault, apropriada e retrabalhada por Rancière. Ela deve ser entendida de antemão como um projeto intelectual que se afasta de nomenclaturas rígidas do fazer ciência e como indissociável da atuação política marcada na biografia de ambos. Como pano de fundo, está a máxima de que não há hierarquia entre diferentes tipos de discurso e saberes. Assim, o que se coloca é uma abordagem metodológica e filosófica complexa atenta às experiências dos indivíduos ordinários, em que subjetivação, conhecimento, igualdade e liberdade são trabalhados por cada autor à sua maneira.

O capítulo seguinte expõe mais precisamente os caminhos distintos tomados por Foucault e Rancière no retrato da configuração do poder, como nas definições de política e polícia; o capítulo três prossegue com as possibilidades de colocação do indivíduo diante do poder segundo os dois pensadores. Nisso, o dissenso ganha uma potência particular para ambos, sobretudo em Rancière, uma vez que oferece um espaço de articulação e colocação diante da hierarquia.

No desenvolvimento do livro, fruto da continuidade de um curso ministrado pelos autores da UFMG em 2017, o leitor tem contato com uma síntese das trajetórias de filiação teórica e com os principais conceitos destes pensadores - conteúdo apresentado de forma bastante instrutiva e clara.

Assim, os autores de Diálogos e dissidências: M. Foucault e J. Rancière mostram como, para Foucault e Rancière, o interesse em comum está no modo como os sujeitos podem configurar experiências emancipatórias - mas o primeiro direciona seu pensamento para observar a emancipação no campo individual da ética, destacando a noção de liberdade; já Rancière privilegia a igualdade como expressão da emancipação enquanto experiência estética e coletiva. Estes pensadores também diferem na abordagem sobre a configuração do poder e a polícia, o que é detalhado no capítulo dois. 
Já o último capítulo, o quarto, consolida a obra de Foucault e Rancière no que diz respeito à ética e a estética, com destaque a uma fase tardia de Foucault, posterior às arqueológica (sujeito construído via discurso) e genealógica (sujeito dominado por relações de poder disciplinar), em que a ética representa as possibilidades de autoconstituição e emancipação pelos sujeitos diante do poder.

Os diálogos e dissidências destes pensadores, apresentados no livro, superam em muito qualquer esquematismo simples sobre semelhanças e diferenças em suas obras. Na verdade, Marques e Prado conduzem a um entendimento consistente, até mesmo para os leitores pouco familiarizados com estas obras, dos caminhos tomados por Foucault e Rancière - que por vezes coincidem em uma mesma trilha, e por outras escolhem espaços e pontos de reflexão diferentes, mas ainda conectados.

\author{
Mariana Freitas Alvim é doutoranda no PPG Comunicação \\ e Semiótica da PUC-SP. É mestre em sociologia pela UFRJ. \\ mariana.alvim@globo.com
}

\title{
Referências
}

FOUCAULT, M. Ditos e escritos, volume IV: estratégia, poder-saber. Org.: Manoel Barros da Motta. Rio de Janeiro: Forense Universitária, 2012.

MARQUES, A. C. S.; PRADO, M. A. M. Diálogos e dissidências: M. Foucault e J. Rancière. Curitiba: Appris, 2018. 